\title{
Conceptualising Functionalism and Its Application to the Study of African History
}

\author{
Mohammed Suleiman Audu \\ Department of History and International Studies \\ Federal University Lokoja, Kogi State \\ Osuala, Uzoma Samuel \\ Department of History and International Studies \\ Federal University Lokoja, Kogi State
}

\section{Doi:10.5901/ajis.2014.v3n6p225}

\begin{abstract}
An old analogy pictures human society as a giant organism composed of many structures, all functioning in an integrated way to maintain the whole system, just as our livers, lungs, kidneys and other organs function to maintain the vitality of our entire body. Therefore, for anyone to understand any given structure, one must determine its function in society. This has given rise to what is known as the structural-functional school of sociology or more briefly, as functionalism. In the same vein, the main stream of history has to do with human development. Throughout history, man has had to meet challenges such as earning a living, dwelling together in harmony with fellow-men, establishing a just and efficient government, expressing his creative talents, and achieving a satisfactory spiritual life. The present has grown out of the past, and if we want to understand our contemporary world, we shall have to look at its roots in history. This paper, therefore, is an attempt at reconciling these symbiotic concepts - History and functionalism and showing how indispensable they are in the Contemporary African Society. To this end therefore, this paper shall focus on the theory of functionalism in various perspectives and its application to African history.
\end{abstract}

Keywords: Conceptualising, Functionalism, Application, Africa, History

\section{Concept Clarification}

Functionalism is the belief that a social pattern is best understood, not in terms of its historical origin, but in terms of its consequences for, and functions in a given society. Functionalism views society as an organism in which all parts function in various ways. Society is regarded by functionalists as something which has an existence of its own and has a structure that serves to maintain it.

Functionalism is inextricably tied up with the question of order. How is order maintained in a society? Order, stability, cohesion and integration are maintained in society by its parts. These parts are social institutions, like the family and the church which exhibit permanent features and whose existence is "useful" or functional.

Pioneer functionalists like Emile Durkheim, Radcliff-Brown, Talcott Parsons and Robert Merton have different views about functionalism.

Durkheim argued that the sociologist's task was first to explain the cause of any social phenomenon e.g. religion and to explain the function it fulfills. To him, 'function' is more suitable than 'purpose' because institutions are not always conscious of the consequences of their existence.

Brown on the other hand said as the word 'function' is being used, the life of an organism is conceived as the functioning of its structure. It is through and by the continuity of it, that the structure is preserved. If we consider any recurrent part of life process, such as respiration, digestion etc., its function is the part it plays in the contribution it makes to the life of the organism as a whole.

Parsons on his part assumed that the complexity of any society must be based on some sort of systematic organization and all societies must share some elements of organization in common. According to Parsons, all social systems have to resolve two sets of problems i.e. 'instrumental' (achieving certain end) and 'expressive' (maintaining efficient cooperation between individuals). The 'functional' imperatives or problems made up the GAlL model of Parsons.

G - Goal attainment

A - Adaption 
I - Integration

L - Latency

Merton on the other hand distinguishes between "Manifest" and "Latent" functions. He defined Manifest functions as those consequences which are both intended and recognized and latent functions as those which are neither intended nor recognized.

Having looked at the views of some functionalists, it will be pertinent to examine the application of this theory in human society based on such phenomena as education, religion, stratification and deviance. Functionalists view society as an integrated, harmonious, cohesive whole where all the parts function to maintain equilibrium and consensus. Thus, a functionalist looking at any institution in society would ask what are the functions that institution performs?

In this case, the functionalist perspective can be applied to education. Durkheim focused on function of socialization when emphasizing the relationship between education and society. Parsons agreed and said that "the school class can be treated as an agency through which individual personalities are trained to be motivationally and technically adequate to the performance of adult roles".

This perspective can be applied to other institutions such as religion in exactly the same sort of way. Functionalists believe that the most genial function of religion is to help an individual to overcome fear and anxiety and to find peace of mind. Perhaps the function which is most commonly identified by functionalists is that of social control through the propagation and legitimization of values. The maintenance of social order is heavily dependent on a high degree of value consensus and by adding divine sanction to human values. Religion buttresses the norms of societies and unites its adherents into a moral community whose members feel a deep common bond.

If we apply this perspective to stratification, it will yield similar results. Social inequality is inevitable, functional and fulfills societal needs. As a functioning mechanism, a society must somehow distribute its members in social position and induce them to perform the duties of these positions.

The functionalists believe that if all jobs in the society were equally pleasant, equally rewarding, equally important and require equal skills and same wage, then it would not matter who got into which job. But this does not exist. Some jobs offer more intrinsic satisfaction, demand more skill and more training and so are more important than others. To solve this problem, the functionalists believed that the society will evolve the social inequality device whereby societies ensure that the most important positions are conscientiously filled by the most qualified persons.

In this same vein, we can ask what are the functions of deviance or crime? The society might tend to see deviance as dysfunctional in so far as they threaten the social order and harmony. Functionalists' perception of deviance from norms only serves to highlight the existence of such norms and to confirm them in the individuals. Deviance from the functionalist approach reinforces and sustains the collective consciousness of consensus.

\section{Its Application to African History}

Functionalism is best understood not in terms of its historical origin, but in terms of its consequences for, and functions in a given society. Society is regarded by functionalists as something which has an existence of its own and has a structure that serves to maintain it.

The theory of functionalism when applied to historical phenomenon could help explain the various functions of the organ of history. When history is divorced from the society, then a vital component of the society will be lacking thereby rendering the entire system ineffective or not functional.

The various sources of history are the vital components of history which make history a whole. The absence of one of these organs would render history non-functional. In this regard, the various sources of history and how they function to inject life into the entire historical phenomenon will be the focus in this section of the paper. This will be done with a view to explaining the continuity between historical events and the society.

Oral source takes its place as a real living museum, conserver and transmitter of the social and cultural creations stored-up by people said to have no written records. Those who are its custodians are hoary-headed old men with cracked voices and often-dimmed memories. However, the oral source does not inspire confidence because it is functional. In any case, every human message is by definition functional including archives which by their very passiveness, neutrality and objectivity; conceal so many lies by omission.

The written source is the past record of men that are committed to writing. Written sources, if not very rare, are at least unevenly distributed in time and space. The most obscure centuries in African history are those which lack the clear and precise illumination that comes from written accounts. Of course, there are contemporary written sources. Be that as it may, written accounts are bound to freeze and dry up. 
Archeological source is the study of cultural remains. Its marvelous discoveries of African past have already served African history when neither oral nor written chronicle was available. The objects alone, buried with those for whom they bear witness, keep vigil beneath the earth. Some of these objects are significant as parts of reference in the measuring of civilization.

Linguistic and Anthropological studies enable an historian to properly study and harness the entire system for proper functioning of the various systems that make up the society. Linguists can tell by comparing the languages of the peoples of West Africa which groups are closely related to each other. They can tell how long ago two peoples who once shared the same language began to develop their own separate languages.

Anthropologist study man as he occurs at all known time and places. They study man's body and soul and examine him as a bodily organism subject to the condition in time and space. Surviving customs and traditions also often give assistance to historians.

Botanists can also help man in the study of history by examining the distribution of plants. They can tell man which plants were indigenous, that is those that belonged originally to Africa, and which plants were introduced from overseas.

So, the main source of African history as outlined above, cannot be arranged a priori according to a scale of values which makes some permanently more important than others. All can be defined as indications which come to us from the past, and which, as the channels of messages are, not entirely neutral and objective but are functional or "useful" and contain intention (manifest function) opened or concealed and recognized.

Functionalisms of Malinowski and Radcliffe-Brown have often regarded Africa as the passive outlet of inventions from elsewhere. They denied primitive societies any historical dimension. Functionalist approaches to African history which in fact contributed little to the understanding of exotic societies, were invalidated still further by the fact that they concentrated precisely on those societies which were strangest to them. The societies they selected were merely microorganism. Thus, the whole of Africa was presented in images which Africans themselves might regard as 'strangest'.

\section{Conclusion}

With all these put together, an historian creates a functional system in the entire society through the blending of the whole societal organism which make up a working whole. Therefore, functionalism is an instrumental web in the integration of African societies, culture and history. Its relevance is promising as propounded by renowned scholars who had pioneered the concept.

\section{Bibliography}

Brown-Radcliff, A.R., (1952). Structure and Function in Primitive Society. London: Cohen and West. Crowther, M., (1977). West Africa: An Introduction to Its History. London: Longman.

Durkheim E. (1964). Rule of Sociological Method. Free Press.

Fajana, A. \& Biggs, B.J. (1964). Nigeria in History. Longman.

Parsons, T. (1964). Economy and Society. Free Press.

Patrick M. and Charle T. (Eds.) (1981). Fundamentals of Sociology. London: Hutchinson.

Robin H. (1980). African Since 1875. London: Heinemann.

Spencer, M. (1976). Foundations of Modern Sociology. New Jersy: Prentice-Hall.

Sydney H.Z. \& Sydney S. (1963). Past to Present. A World History. London: Macmillan. 
